\title{
HUBUNGAN MOTIVASI DENGAN PERILAKU SWAMEDIKASI
}

\author{
Erina Efayanti, Tri Susilowati*, Ida Nur Imamah \\ Program Studi Sarjana Keperawatan, Stikes 'Aisyiyah Surakarta, J1. Ki Hajar Dewantara No.10, Jebres, Kec. \\ Jebres, Kota Surakarta, Jawa Tengah, Indonesia 57126 \\ *asaku_susi@yahoo.com $(+6285647416651)$
}

\begin{abstract}
ABSTRAK
Swamedikasi adalah upaya pengobatan diri sendiri, biasanya dilakukan untuk mengatasi penyakit ringan, seperti demam, nyeri, pusing, batuk, influenza, diare, penyakit kulit. Badan Pusat Statistik mengatakan bahwa masyarakat Indonesia yang melakukan swamedikasi sebesar 72,44\%. Penelitian bertujuan untuk mengetahui hubungan motivasi dengan perilaku swamedikasi di Apotek Suganda Tangen Sragen. Penelitian analitik dengan rancangan penelitian cross sectional. Pengambilan sampel menggunakan tekhnik quota sampling dengan jumlah 90 responden, dengan subjek penelitian ini adalah pembeli yang membeli obat tanpa menggunakan resep dari dokter di Apotek Suganda Tangen Sragen, sedangkan instrument penelitian ini menggunakan kuesioner, analisa bivariate menggunakan uji Chi Square dengan taraf signifikasi $(0,05)$. Hasil analisa univariate sebagian besar responden memiliki motivasi yang tinggi sebanyak 42 responden(46,7\%), perilaku swamedikasi menunjukkan sebagian besar responden memiliki perilaku yang baik sebanyak 38 responden (42,2\%). Hasil analisa bivariate menunjukkan nilai Exact Sig. (2-sided) $(0,000)<0,05$. Terdapat hubungan motivasi dengan perilaku swamedikasi di Apotek Suganda Tangen Sragen.
\end{abstract}

Kata kunci : motivasi, perilaku, swamedikasi

\section{RELATIONSHIP OF MOTIVATION WITH THE BEHAVIOR OF SELF MEDICATION}

\begin{abstract}
Self-medication is an attempt self-medication, usually done to cope with minor illnesses, such as fever, pain, dizziness, cough, influenza, diarrhea, skin diseases.The Central Statistics Agency said that the Indonesian people who self-medication were 72,44\%. The purpose of relationship of motivation with the behavior of self-medicationat theSugandaPharmacy Tangen Sragen. Analytical research with cross sectional research design. Sampling using the dwarf quota sampling with a population of 90 respondents, with the subject of the research is the buyer who bought drugs without the use of a prescription from a Medical Doctor at theSuganda Pharmacy Tangen Sragen, while this research instrument using bivariate analysis questionnaires, using test Chi Square with the significance level (0.05). The results of the univariate analysis most respondents have a high motivation as much as 42 respondents (46,7\%), behavioural self-medication showed most respondents have good behavior as much as 38 respondents (42.2\%). Bivariate analysis results show the Exact value of the Sig $(2$-sided $)(0.000)<0.05$. There is a relationship of motivation with the behavior of self-medicationat theSuganda Pharmacy Tangen Sragen.
\end{abstract}

Keywords: motivation, behavior, self-medication 


\section{PENDAHULUAN}

Kesehatan adalah salah satu hal yang sangat penting dalam kehidupan, jika seseorang sakit maka seseorang akan berusaha untuk sehat kembali. Hal yang biasa dilakukan seseorang untuk sembuh, yaitu berobat ke dokter atau mengobati diri sendiri. Pengobatan sendiri atau yang biasa disebut swamedikasi adalah hal yang paling sering di lakukan masyarakat sebelum ke tenaga kesehatan (Adawiyah et al., 2017:110).

Swamedikasi adalah upaya pengobatan diri sendiri, biasanya dilakukan untuk mengatasi penyakit ringan, seperti demam, nyeri, pusing, batuk, influenza, diare, penyakit kulit. Swamedikasi menjadi pilihan masyarakat untuk meningkatkan keterjangkauan pengobatan. Masyarakat memerlukan pedoman yang terpadu agar tidak terjadi kesalahan pengobatan saat melakukan swamedikasi (Restiyono, 2016:15).

Pengobatan sendiri yang sesuai aturan adalah apabila cara menggunakan obat sesuai dengan aturan yang tercantum dalam kemasan. Obat yang aman digunakan untuk pengobatan sendiri yaitu golongan obat bebas dan bebas terbatas relatif. Obat-obatan yang biasa digunakan untuk swamedikasi disebut dengan obat tanpa resep atau obat bebas. Obat-obat bebas tersebut dapat diperoleh di warung, apotek, dan supermarket. Sebaliknya, obat yang diperoleh dengan resep dokter biasa disebut obat resep (Manan, 2014:12).

Badan Pusat Statistik (BPS) pada tahun 2014 mengatakan bahwa data yang diperoleh tentang swamedikasi oleh masyarakat Indonesia dari tahun 2002 sampai dengan tahun 2014 untuk pengobatan modern sebesar 86,68\% ; pengobatan tradisional $32,90 \%$. Hasil ini juga didukung oleh indikator kesehatan dari BPS yang menyatakan presentase masyarakat yang melakukan pengobatan sendiri sebesar $72,44 \%$, sedangkan yang melakukan pengobatan ke dokter sebesar 38,21\% (BPS,2016). Data tersebut menunjukkan bahwa masyarakat lebih memilih melakukan pengobatan sendiri atau swamedikasi dibanding dengan periksa ke dokter (Syafitri et al., 2017:20). Badan Pusat Statistik (BPS) pada tahun 2014 mengatakan bahwa data yang diperoleh tentang swamedikasi di Jawa Tengah pada tahun 2014 untuk pengobatan modern sebesar 90,55\%, pengobatan tradisional sebesar $17 \%$. Data tersebut menunjukkan bahwa masyarakat di Jawa Tengah lebih banyak menggunakan obat modern dibandingkan dengan obat tradisional.

Swamedikasi bila dilakukan secara rasional dapat bermanfaat baik bagi pasien, tenaga kesehatan, maupun pemerintah. Manfaat yang pertama, dapat membantu pasien untuk mencegah dan mengobati gejala ringan secara mandiri. Kedua, dapat menurunkan beban kerja tenaga kesehatan terkait penanganan keluhan ringan. Ketiga, dapat menurunkan biaya pengobatan pasien terutama pada era Badan Penyelenggara Jaminan Sosial (BPJS) Kesehatan. Swamedikasi akan menimbulkan masalah baru jika dilakukan secara tidak benar yaitu tidak sembuhnya penyakit karena adanya resistensi bakteri dan ketergantungan (Halim et al., 2018:87).

Hasil penelitian yang dilakukan oleh Pratiwi et al (2014:40) yaitu pengaruh pengetahuan terhadap perilaku swamedikasi obat anti-inflamasi non 
steroid-oral pada etnis thionghoa di Surabaya, mendapatkan hasil $41 \%$ responden memiliki pengetahuan yang cukup dan $99 \%$ responden melakukan perilaku swamedikasi yang benar. Halim et al (2018) menyatakan bahwa dari penelitian menunjukkan salah satu obat yang paling banyak digunakan secara swamedikasi adalah analgetik. NonSteroidal Anti Inflammatory Drugs (NSAIDs) merupakan jenis yang paling populer di masyarakat. Keluhan yang sering dialami masyarakat sehingga masyarakat terdorong untuk menggunakan analgesik secara swamedikasi antara lain : sakit kepala, nyeri sendi, dan sakit gigi.

Obat analgetik merupakan senyawa yang dapat meringankan atau menekan rasa sakit, tanpa memiliki kerja anastesi umum sehingga dapat meringankan rasa nyeri dan memberikan rasa nyaman. Penggunaan obat analgetik yang sesuai dengan resep dokter sangat membantu untuk mengatasi nyeri. Penggunaan obat yang tidak tepat dapat memberikan efek samping seperti mual, maag, resiko perdarahan, telinga berdengung, dan lainlain (Trilia et al., 2017:304).

Seseorang dalam melakukan tindakan biasanya mendapat keinginan atau dorongan, baik dari dalam diri sendiri maupun dari orang lain. Hal ini disebut sebagai motivasi. Motivasi merupakan akibat dari suatu hasil yang ingin dicapai oleh seseorang dan perkiraan bahwa tindakannya akan mengarah ke hasil yang diinginkan. Hal tersebut terjadi apabila seseorang menginginkan kesembuhan dan jalannya tampak terbuka untuk memperolehnya, maka seseorang akan berupaya untuk mendapatkannya (Ermawati, 2018:93). Motivasi sebagai proses, arah dan usaha seseorang untuk mencapai sebuah tujuan. Motivasi merupakan kondisi atau kekuatan yang mendorong seseorang untuk bergerak ke arah yang diharapkan untuk mencapai tujuan (Gultom, 2014:180).

Berdasarkan fenomena yang ada di Sragen, bahwa masyarakat lebih memilih membeli obat di warung maupun di apotek karena dianggap lebih murah dan cepat. Studi pendahuluan yang sudah dilakukan peneliti di Apotek Suganda Kecamatan Tangen Kabupaten Sragen, diperoleh data bahwa Tangen merupakan salah satu kecamatan yang jauh dari perkotaan dan pelayanan kesehatan. Apotek Suganda Tangen merupakan satusatunya Apotek yang ada di Tangen. Data yang diperoleh dari Apotek Suganda Tangen, diperoleh data 9 dari 10 pembeli ternyata membeli obat tanpa menggunakan resep. Obat yang paling sering dibeli tanpa menggunakan resep yaitu obat analgetik dan obat gatal. Alasan pembeli membeli obat tersebut yaitu karena pembeli pernah mengkonsumsi obat yang sama dan obat tersebut dapat mengurangi gejala penyakitnya. Sebagian besar penduduk lebih mengkonsumsi obat tanpa menggunakan resep dokter dimana mereka tidak mengetahui efek samping dari penggunaan obat tanpa resep dalam jangka waktu yang lama dan masih mempunyai pemikiran yang sederhana dalam pengobatan yaitu asal murah dan cepat. Berdasarkan hasil uraian tersebut, peneliti tertarik untuk mengetahui motivasi masyarakat dalam melakukan swamedikasi, mengetahui perilaku swamedikasi masyarakat dan menganalisis hubungan motivasi dengan perilaku swamedikasi. 


\section{METODE}

Penelitian ini menggunakan rancangan cross sectional.Populasi pada penelitian ini yaitu semua pembeli obat di Apotek Suganda Tangen Sragen sebanyak 868 orang.Sampel dalam penelitian ini diambil dengan menggunakan quota sampling yaitu 90 responden.Kriteria inklusi pada penelitian ini adalah : responden yang melakukan swamedikasi, laki - laki dan perempuan, sedangkan kriteria eksklusinya adalah responden yang membawa resep dokter. Lokasi Penelitian Dilaksanakan Di Apotek Suganda Tangen Sragen.Instrument yang digunakan dalam pengumpulan data berupa kuesioner (daftar pertanyaan atau pernyataan) dan formulir-formulir lain yang berkaitan dengan pencatatan data dan sebagainya.Metode pengumpulan data adalah angket atau kuesioner untuk mengetahui motivasi dan perilaku swamedikasi pada responden.Variabel yang dianalisis secara univariat dalam penelitian ini adalah motivasi dan perilaku swamedikasi. Uji yang digunakan pada analisa bivariate ini adalah Chi square atau kai-kuadrat $\left(\mathrm{x}^{2}\right)$.

\section{HASIL}

1. Umur Responden

Karakteristik responden berdasarkan umur dapat dilihat dari tabel dibawah ini:

Tabel 1

Distribusi Responden Berdasarkan Umur yang Melakukan Swamedikasi ( $\mathrm{n}=90)$

\begin{tabular}{llc}
\hline \multicolumn{1}{c}{ Kategori Umur } & $\mathrm{f}$ & $\%$ \\
\hline Remaja (12-25 tahun) & 43 & 47,8 \\
Dewasa (26-45 tahun) & 38 & 42,2 \\
Lansia (46-65 tahun) & 9 & 10 \\
\hline Distribusi responden berdasarkan umur & laki-laki atau perempuan memiliki \\
menunjukkan sebagian besar responden & kesempatan yang sama untuk menjadi \\
berumur remaja sebanyak 43 responden & sampel penelitian. Berdasarkan hasil \\
(47,8\%). & analisis univariat, berikut data jenis \\
& kelamin responden yang disajikan dalam \\
2. Jenis Kelamin & table berikut ini.
\end{tabular}

kelamin tertentu. Semua responden baik

Tabel 2

Distribusi responden berdasarkan jenis kelamin yang melakukan swamedikasi $(n=90)$

\begin{tabular}{|c|c|c|}
\hline Jenis Kelamin & $\mathrm{f}$ & $\%$ \\
\hline Laki-laki & 38 & 42.2 \\
\hline Perempuan & 52 & 57.8 \\
\hline
\end{tabular}

Sebagaimana dalam table di atas, diketahui, jenis kelamin paling banyak adalah perempuan yaitu 52 atau $57,8 \%$.
3. Tingkat Pendidikan

Pendidikan responden yang diteliti juga berbeda-beda. Berdasarkan hasil analisis univariat diketahui masing-masing pendidikan responden disajikan dalam table berikut 
Tabel 3.

Distribusi responden berdasarkan tingkat pendidikan yang melakukan swamedikasi $(\mathrm{n}=90)$

\begin{tabular}{|c|c|c|}
\hline Pendidikan & $\mathrm{f}$ & $\%$ \\
\hline SD & 18 & 20.0 \\
\hline SLTP & 16 & 17.8 \\
\hline SLTA & 44 & 48.9 \\
\hline D3 & 12 & 13.3 \\
\hline
\end{tabular}

Sebagaimana dalam tabel di atas, diketahui, pendidikan responden paling banyak adalah SLTA yaitu 44 atau $48,9 \%$.

\section{Pekerjaan}

Pekerjaan responden berbeda-beda. Berdasarkan hasil analisis univariat diketahui masing-masing pekerjaan responden disajikan dalam table berikut

Tabel 4.

Distribusi responden berdasarkan pekerjaan yang melakukan swamedikasi $(n=90)$

\begin{tabular}{lccc}
\hline & Pekerjaan & $\mathrm{f}$ & $\%$ \\
\hline Buruh & 13 & 14.4 \\
lain-lain & 25 & 27.8 \\
Pedagang & 9 & 10.0 \\
Petani & 16 & 17.8 \\
Tidak Bekerja & 27 & 30.0 \\
\hline
\end{tabular}

Sebagaimana dalam tabel 4, diketahui, pekerjaan responden paling banyak adalah tidak bekerja yaitu 27 atau $30 \%$.
5. Jenis Obat

Jenis obat yang dibeli masyarakat dapat dilihat pada tabel 5 berikut ini.

Tabel 5

Distribusi Responden Berdasarkan Jenis Obat yang Dibeli oleh Masyarakat ( $\mathrm{n}=90)$

\begin{tabular}{lcc}
\hline \multicolumn{1}{c}{ Jenis Obat } & f & $\%$ \\
\hline Obat Analgetik & 43 & 47,8 \\
Obat Antinflamasi & 2 & 2,2 \\
Obat Antipiretik & 10 & 11,1 \\
Obat Antihistamin & 35 & 38,9
\end{tabular}

Sebagaimana dalam tabel 6, diketahui, jenis obat yang paling banyak dibeli responden adalah obat analgetik yaitu 43 atau $47,8 \%$.

\section{Motivasi}

Variabel yang diteliti dalam penelitian ini adalah motivasi.Hasil penelitian motivasi diklasifikasi menjadi 3 kelompok.Berdasarkan hasil analisis univariat diketahui. 
Tabel 6

Distribusi responden berdasarkan motivasi yang melakukan swamedikasi $(\mathrm{n}=90)$

\begin{tabular}{lll}
\hline Motivasi Rendah & 25 & 27.8 \\
Motivasi Sedang & 23 & 25.6 \\
Motivasi Tinggi & 42 & 46.7 \\
\hline
\end{tabular}

Berdasarkan hasil analisis, diketahui tingkat motivasi yang paling banyak adalah motivasi tinggi, yaitu 42 responden atau $46,7 \%$.
7. Perilaku Swamedikasi

Penelitian ini hendak mengetahui perilaku swamedikasi responden. Adapun hasil analisis univariat diketahui.

Tabel 7

Distribusi responden berdasarkan perilaku swamedikasi yang melakukan swamedikasi

\begin{tabular}{lcc}
\multicolumn{1}{c}{$(\mathrm{n}=90)$} & & \\
\hline Perilaku Swamedikasi & $\mathrm{f}$ & $\%$ \\
\hline Perilaku Kurang & 21 & 23.3 \\
Perilaku Cukup & 31 & 34.4 \\
Perilaku Baik & 38 & 42.2 \\
\hline
\end{tabular}

Tabel 7, diketahui perilaku swamedikasi responden yang paling dominan adalah perilaku swamedikasi baik, yaitu sebanyak 38 responden atau $42,2 \%$
8. Hubungan Antara Motivasi Dengan Perilaku Swamedikasi.

Berikut tabulasi silang hubungan motivasi dengan perilaku swamedikasi :

Tabel 8

Distribusi frekuensi hubungan motivasi dengan perilaku swamedikasi $(n=90)$

\begin{tabular}{|c|c|c|c|c|c|c|c|c|c|}
\hline & & \multicolumn{8}{|c|}{ Perilaku Swamedikasi } \\
\hline \multirow{5}{*}{ Motivasi } & \multirow{5}{*}{$\begin{array}{l}\text { Rendah } \\
\text { Sedang } \\
\text { Tinggi }\end{array}$} & \multicolumn{2}{|c|}{ Kurang } & \multicolumn{2}{|c|}{ Cukup } & \multicolumn{2}{|c|}{ Baik } & \multicolumn{2}{|c|}{ Total } \\
\hline & & f & $\%$ & $\mathrm{f}$ & $\%$ & $\mathrm{f}$ & $\%$ & $\mathrm{f}$ & $\%$ \\
\hline & & 12 & 13,3 & 11 & 12,2 & 2 & 2,2 & 25 & 27,8 \\
\hline & & 7 & 7,8 & 13 & 14,4 & 3 & 3,3 & 23 & 25,6 \\
\hline & & 2 & 2,2 & 7 & 7,8 & 33 & 36,7 & 42 & 46,7 \\
\hline
\end{tabular}

Tabel 9

Hasil analisis Hubungan Motivasi Dengan Perilaku Swamedikasi ( $\mathrm{n}=90)$

\begin{tabular}{lcc}
\hline Variabel & $\chi 2$ & $\rho$ value \\
\hline Motivasi dengan perilaku swamedikasi & 45,711 & 0,000 \\
\hline Setelah dilakukan analisi data dengan uji & hubungan yang signifikan antara motivasi \\
Chi Square dengan nilai $\chi 2$ sebesar & dengan perilaku swamedikasi.
\end{tabular}

45.711 dengan $\rho$ value sebesar 0,000 , karena nilai $\rho=0,000<0,05$; maka Ha diterima dan Ho ditolak, artinya terdapat 


\section{PEMBAHASAN}

\section{Motivasi}

Berdasarkan hasil penelitian tentang motivasi masyarakat melakukan swamedikasi di Apotek Suganda Tangen Sragen, didapatkan bahwa sebagian besar memiliki motivasi tinggi.Dari hasil menunjukkan jumlah masyarakat yang memiliki motivasi tinggi lebih banyak dibandingkan yang memiliki motivasi lebih rendah.

Hasil penelitian Rinukti (2014) memberi gambaran bahwa faktor yang paling berperan mendorong penggunaan produk obat demam tanpa resep adalah motivasi responden sendiri $(85,5 \%)$. Selanjutnya yang mendorong responden menggunakan produk obat demam tanpa resep adalah motivasi dari saudara $(9,1 \%)$ dan iklan (5,5\%). Tidak ada responden yang menjawab bahwa teman juga menjadi faktor yang mendorong penggunaan produk obat demam tanpa resep di RW V Kelurahan Terban.Tiap kegiatan yang dilakukan oleh seseorang didorong oleh kekuatan dari dalam diri orang tersebut, kekuatan inilah yang disebut motivasi. Sebagian responden menjawab bahwa motivasi yang mendorong tindakan penggunaan produk obat demam tanpa resep datang dari sendiri. Hal ini menunjukkan bahwa tindakan penggunaan produk obat demam tanpa resep dihasilkan oleh kesadaran akan kebutuhan dari dalam diri individu sendiri.

Penelitian ini sejalan dengan hasil penelitian oleh Widayati (2017) yang menunjukkan bahwa ada hubungan yang positif dan signifikan antara motivasi dengan perilaku swamedikasi untuk penyakit keputihan (kandidiasis vaginal) dan antara pengetahuan dengan perilaku
swamedikasi.Artinya, semakin besar motivasi dan pengetahuan semakin meningkat pula perilaku swamedikasi mereka untuk penyakit keputihan (kandidiasis vaginal).

Hasil penelitian menunjukkan mayoritas responden berumur remaja (12-25 tahun). Menurut Dianawati et al (2008) didalam Adawiyah et al ( 2017) menyatakan bahwa pada usia remaja mulai mempunyai keinginan untuk membuat keputusan sendiri dan mencoba sesuatu yang baru dan menarik. Adanya televisi memberikan rekomendasi bagi remaja untuk pemilihan dan penggunaan obat. Responden mayoritas berjenis kelamin perempuan.

Hebeeb dan Geahart (1993) didalam Maria (2017) menyatakan bahwa jenis kelamin berhubungan dengan perilaku pengobatan sendiri dan responden perempuan lebih banyak melakukan pengobatan sendiri secara rasional.dalam penelitiannya juga menyatakan bahwa perempuan adalah pelaku tindakan swamedikasi dengan modalitas tinggi dibandingkan pria, baik untuk dirinya sendiri maupun untuk keluarganya. Pada penelitian Kristina et al (2008) didalam Maria (2017) diperoleh hasil bahwa pendidikan, jenis kelamin dan pekerjaan secara bersama-sama berpengaruh terhadap perilaku penggunaan obat yang rasional pada swamedikasi. Akan tetapi faktor pendidikan merupakan faktor yang paling besar pengaruhnya karena orangorang dengan pendidikan tinggi umumnya tidak mudah terpengaruh oleh iklan dan lebih banyak membaca label pada kemasan obat sebelum mengkonsumsinya. Hasil temuan tersebut, peneliti berpendapat bahwa motivasi merupakan salah satu penyebab 
orang melakukan swamedikasi. Motivasi dalam diri sendiri akan lebih kuat daripada motivasi yang berasal dari luar yang datang dari keluarga, teman maupun lingkungan sekitar. Motivasi yang tinggi akan membuat seseorang berperilaku. Selain itu, pendidikan, jenis kelamin dan pekerjaan juga berpengaruh terhadap perilaku swamedikasi. Pada hal ini masyarakat akan berperilaku berobat untuk mendapatkan kesembuhan. Baik dengan cara memeriksakan ke dokter maupun ke pelayanan kesehatan atau dengan cara membeli obat sendiri di Apotek maupun di Warung. Sebagian besar responden lebih memilih membeli obat sendiri karena dianggap lebih mudah dan cepat.

\section{Perilaku Swamedikasi}

Berdasarkan hasil penelitian tentang perilaku swamedikasi masyarakat di Apotek Suganda Tangen Sragen, didapatkan bahwa sebagian besar memiliki perilaku baik.Dari hasil tersebut menunjukkan jumlah orang yang berperilaku swamedikasi baik lebih banyak dibandingkan yang kurang baik. Perilaku merupakan suatu aktivitas seseorang yang bersangkutan, yang dapat dilihat secara langsung maupun tidak langsung.Perilaku manusia adalah suatu aktivitas atau tindakan dari manusia itu sendiri (Donsu, 2017). Swamedikasi adalah upaya pengobatan diri sendiri, biasanya dilakukan untuk mengatasi penyakit ringan, seperti demam, nyeri, pusing, batuk, influenza, diare, penyakit kulit (Restiyono,2016). Perilaku swamedikasi adalah suatu tindakan yang dilakukan seseorang dalam pengobatan diri sendiri untuk mengatasi penyakit ringan.Pelaksanaan swamedikasi di masyarakat dimaksudkan untuk mengatasi gangguan kesehatan ringan, salah satunya adalah nyeri. Pelaksanaan swamedikasi nyeri mencapai $17,9 \%$ dari keseluruhan swamedikasi yang dilakukan (Muharni et al, 2017). Obat yang paling sering di beli masyarakat adalah obat jenis analgetik dan obat influenza dengan keluhan pusing, pegal linu, batuk pilek dan lain-lain. Masyarakat yang membeli obat di Apotek Suganda Tangen Sragen melakukan swamedikasi karena swamedikasi lebih mempermudah mereka untuk mendapatkan obat, selain itu masyarakat tidak perlu mengeluarkan biaya untuk membayar periksa ke dokter serta jarak rumah warga ke pelayanan kesehatan cukup jauh, Sehingga masyarakat lebih memilih membeli obat di warung ataupun apotek.

Hasil penelitian Maria (2017) tentang kajian perilaku swamedikasi menggunakan penggemuk badan di Apotek menjelaskan bahwa perilaku swamedikasi pasien pengunjung apotek diperoleh pasien yang sudah tahu obat penggemuk badan sebanyak 62,04\% . Pasien yang memperoleh obat penggemuk badan tersebut dengan langsung membeli tanpa periksa (35,19\%). Menurut Raharja \& Tjai (2010), Swamedikasi apabila dilakukan secara benar akanmemberikan kontribusi yang besar bagi pemerintah dalam pemeliharaan kesejahteraan secara nasional. Namun bila tidak dilakukan secara benar, justru dapat menimbulkan bencana yaitu tidak sembuhnya penyakit atau bahkan bisa muncul penyakit baru akibat pemakaian obat yang kurang tepat. Pelaksanaan swamedikasi didasari oleh pemikiran bahwa pengobatan sendiri cukup untuk mengobati masalah kesehatan yang dialami tanpa melibatkan tenaga kesehatan (Hermawati, 2012). 
Swamedikasi menjadi alternatif yang diambil masyarakat untuk meningkatkan keterjangkauan pengobatan masyarakat sehingga memerlukan pedoman yang terpadu agar tidak terjadi kesalahan pengobatan.Perlunya pemahaman yang baik serta peran serta apoteker sebagai pemberi pelayanan sangat dibutuhkan guna mencapai perilaku swamedikasi yang baik.Menurut pandangan peneliti perilaku swamedikasi individu atau seseorang sudah menunjukkan perilaku yang adaptif dan positif.Hal ini dapat dilihat dari kebiasaan responden ketika sakit langsung mengobati dirinya sendiri dengan membeli obat di apotik. Selain itu dipengaruhi juga oleh pengalaman sakit sebelumnya sehingga sudah mengerti apa yang seharusnya dilakukan untuk mengobati sakit yang dialami.

3. Hubungan Motivasi dengan Perilaku Swamedikasi Di Apotek

Hasil penelitian menunjukkan bahwa terdapat hubungan antara motivasi dengan perilaku swamedikasi di Apotek Suganda Tangen Sragen.Artinya semakin tinggi motivasi semakin tinggi pula seseorang untuk berperilaku.

Hasil penelitian ini selaras dengan penelitian Widayati (2013) yang menyatakan bahwa terdapat hubungan positif dan signifikan antara motivasi dengan perilaku swamedikasi untuk penyakit keputihan (kandidiasis vaginal) oleh wanita pengunjung apotek di kota Yogyakarta periode Agustus, dengan tingkat hubungan kuat. Terdapat hubungan yang positif dan signifikan antara pengetahuan dengan perilaku swamedikasi untuk penyakit keputihan (kandidiasis vaginal) oleh wanita pengunjung apotek di kota Yogyakarta periode Agustus, dengan tingkat hubungan rendah.
Hasil penelitian Rinukti (2005) yang menyatakan bahwa terdapat hubungan antara variabel motivasi dengan tindakan penggunaan produk obat demam tanpa resep oleh orang tua untuk anak-anak di RW V Kelurahan Terban dengan koefisien korelasi sebesar 0,489. Hasil penelitian ini juga menunjukkan adanya hubungan yang positif dan signifikan antara pengetahuan dengan tindakan penggunaan produk obat demam oleh orang tua ungtuk anak-anak di RW V Kelurahan turban dengan koefisien korelasi sebesar 0,301.

Berdasarkan temuan diatas, peneliti memandang bahwa motivasi memiliki keterkaitan dengan perilaku swamedikasi. Hal tersebut menunjukkan bahwa seseorang ketika mengalami sakit atau masalah dengan kesehatannya tentu akan mencari pengobatan sendiri. Baik yang diperoleh dari apotek maupun dari warung.Hal tersebut didasari oleh pengalaman sembuh menggunakan obat sebelumnya, persepsi diri tentang penyakitnya yang ringan, harga yang relatif murah, cepat dan praktis. Menurut pandangan peneliti, swamedikasi masyarakat cukup baik, namun masih banyak masyarakat yang belum mengaplikasikan sikap mereka pada saat melakukan swamedikasi. Karena masih banyak responden yang pada saat melakukan swamedikasi kurang membaca label yang tertera pada kemasan obat yang dikonsumsi. Juga kurang bertanya pada apoteker/petugas apotek tentang obat yang di konsumsi. Jadi masih mungkin akan terjadinya kesalahan pengobatan (medication error). Hal ini berarti keterkaitan antara motivasi dengan perilaku swamedikasi tidak menjamin masyarakat untuk tidak melakukan swamedikasi. Masyarakat justru akan 
beranggapan bahwa ketika seseorang sakit harus berobat agar segera pulih dari kondisi sakit yang dialaminya sehingga salah satu yang dapat dilakukan yaitu perilaku swamedikasi (pengobatan sendiri).

\section{SIMPULAN}

Mayoritas responden memiliki motivasi tinggi dalam melakukan swamedikasi. Mayoritas responden berperilaku motivasi baik dalam melakukan swamedikasi. Terdapat hubungan antara motivasi dengan perilaku swamedikasi.

\section{DAFTAR PUSTAKA}

Adawiyah, S., Cahaya, N., dan Intannia, D. 2017. Hubungan Persepsi Terhadap Iklan Obat Laksatif Di Televisi Dengan Perilaku Swamedikasi Masyarakat Di Kelurahan Sungai Besar Kecamatan Banjarbaru Selatan. PHARMACY 14(1): 110

Donsu, J. D. 2017. Psikologi Keperawatan. Pustaka Baru Press. Yogyakarta

Ermawati, E. 2018. Pengaruh Kompensasi Langsung, Kompensasi Tidak Langsung, Dan Kompensasi Non Financial Terhadap Motivasi Dan Kinerja Karyawan Klinis Swasta Di Kabupaten Lumajang. Progress Conference 1(1): 93

Gultom, D. K. 2014. Pengaruh Budaya Organisasi Perusahaan dan Motivasi Terhadap Kinerja Karyawan Pada PT. Perusahaan Gas Negara (PERSERO) Tbk Medan. Jurnal Manajemen \& Bisnis 14(2): 180
Halim, S. V., Prayitno S, A. A., dan Wibowo, Y. I. 2018. Profil Swamedikasi Analgesik di Masyarakat Surabaya jawa Timur. Jurnal Ilmu Kefarmasian Indonesia 16(1): 87

Hermawati, D. 2012. Pengaruh Edukasi Terhadap Tingkat Pengetahuan Dan Rasionalitas Penggunaan Obat Swamedikasi Pengunjung Di Dua Apotek Kecatamatan Cimanggis, Depok. Skripsi.Universitas Indonesia. Jakarta.

Manan, L. 2014. Buku Pintar Swamedikasi. Cetakan pertama. Saufa. Jogjakarta

Maria, L. K. 2017. Kajian Perilaku Swamedikasi Menggunakan Obat Penggemuk Badan Oleh Pasien Pengunjung Apotek Di Kota Kupang Tahun 2016. Jurnal Info Kesehatan 15(2)

Muharni, S., Ariyani, F., Agustini, T. T., dan Fitriani, D. 2017. Sikap Tenaga Kefarmasian Dalam Penggalian Informasi Pada Swamedikasi Nyeri Gigi Di Apotek-Apotek Kota Pekanbaru Provinsi Riau. Jurnal Penelitian Farmasi Indonesia 5(2)

Pratiwi, Pristianty, Noorrizka, dan Impian. 2014. Pengaruh Pengetahuan Terhadap Perilaku Swamedikasi Obat Anti-Inflamasi Non-Steroid Oral Pada Etnis Thionghoa Di Surabaya.Jurnal Farmasi Komunitas 2(1): 40.

Restiyono, A. 2016. Analisis Faktor yang Berpengaruh dalam Swamedikasi Antibiotik pada Ibu Rumah Tangga Di Kelurahan Kajen Kabupaten 
Pekalongan. Jurnal Promosi Kesehatan Indonesia11(1): 15

Rinukti dan Widayati, 2005, Hubungan Antara Motivasi dan Pengetahuan Orangtua Dengan Tindakan Penggunaan Produk Obat Demam Tanpa Resep Untuk Anak-anak RW $\mathrm{V}$ di Kelurahan Terban Tahun 2004, Sigma Jurnal Sains dan Teknologi Vol. 8 No. 1

Syafitri, I. N., Hidayati, I. R., dan Pristianty, L. 2017. Hubungan Tingkat Pengetahuan terhadap Penggunaan Obat Parasetamol Rasional dalam Swamedikasi.
Jurnal Farmasi Dan Ilmu Kefarmasian Indonesia 4(1): 20

Trilia., Majid, Y. A., Lestari, W. 2017. Hubungan Pengetahuan Dan Sikap Dalam Penggunaan Obat Analgetik Bebas Untuk Pengobatan Sendiri Pada Mahasiswa PSIK Angkatan 2015 STIKes MUHAMMADIYAH PALEMBANG. 5(1): 304

Widayati, A. 2013. Swamedikasi di Kalangan Masyarakat Perkotaan di Kota Yogyakarta. Jurnal Farmasi Klinik Indonesia. Volume 2, Nomor 4. 
Jurnal Penelitian Perawat Profesional, Volume 1 No 1 Hal 21 - 32, November 2019

Global Health Science Group 